\title{
Squamous cell carcinoma endometrium
}

\author{
Nisha Marhatta*, Deepali Raina \\ Department of Obstetrics and Gynecology, Government Medical College, Jammu, Jammu and Kashmir, India
}

Received: 11 June 2015

Revised: 19 June 2015

Accepted: 17 July 2015

\section{*Correspondence:}

Dr. Nisha Marhatta,

E-mail: drnish231286@gmail.com

Copyright: (c) the author(s), publisher and licensee Medip Academy. This is an open-access article distributed under the terms of the Creative Commons Attribution Non-Commercial License, which permits unrestricted non-commercial use, distribution, and reproduction in any medium, provided the original work is properly cited.

\section{ABSTRACT}

Primary pure squamous cell carcinoma (SCC) of endometrium is very rare. About 70 cases have been reported, according to WHO blue book. It is defined as a primary carcinoma of the endometrium composed of squamous cells of varying degree of differentiation. The frequency of SCC of the endometrium is unknown.

Keywords: Endometrium, Squamous cell carcinoma, Uterine bleeding

\section{INTRODUCTION}

Primary pure squamous cell carcinoma (SCC) of endometrium is very rare. About 70 cases have been reported, according to WHO blue book. ${ }^{1}$ It is defined as a primary carcinoma of the endometrium composed of squamous cells of varying degree of differentiation. ${ }^{1}$ The frequency of SCC of the endometrium is unknown.

\section{CASE REPORT}

A 38-year-old woman was admitted with abnormal uterine bleeding since, 3 months. She had her last menstural period 1 month back. She was normotensive, euthyroid and euglycemic with mild anaemia. On per speculum examination her cervix was grossly healthy. Per vaginum examination was suggestive of multiparous size uterus with free parametrium, USG was suggestive of an irregular heterogenous lesion $2 \times 1.5 \mathrm{~cm}$ surrounded by a hypoechoic area in cervical portion of the uterus, interface with bladder was lost and was advised CECT: which was suggestive of bulky uterus and cervix with left parametrial invasion with no lymphadenopathy. Patient underwent Radical Hysterectomy with b/l pelvic lymphadenectomy. Specimen was sent for HPE which suggested moderately differentiated squamous cell carcinoma endometrium with chronic cervicitis and no lymph nodal metastasis. Uterine curettage biopsy and uterine discharge cytology revealed SCC (Figure 1).

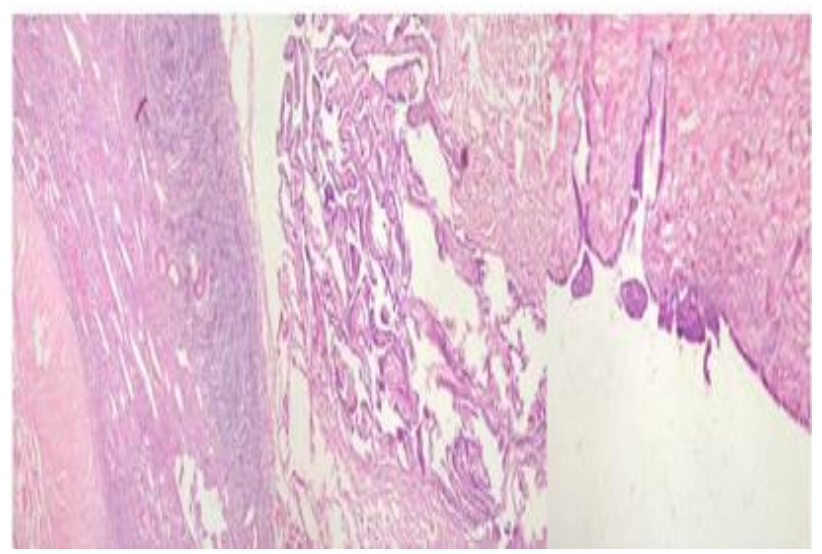

Figure 1: Endometrial biopsy specimen: showing squamous cell carcinoma.

Cervical canal measured $3 \mathrm{~cm}$ in length and did not show any growth. Uterine canal contained a friable growth infiltrating the myometrium. Ovaries and tubes were grossly normal. Sections from the endometrial growth showed a tumour depicting features of Moderately differentiated squamous cell carcinoma infilterating more than $2 / 3$ of the thickness of myometrium. No glandular 
component was seen; even after study of multiple sections from the growth. No tumor cells were seen in other sites including the cervix, ovaries, omentum, and lymph nodes. The patients were FIGO stage IB, and was treated with radiation and adjuvant chemotherapy. She has received 25 cycles of radiotherapy. The patient is now alive without recurrence and metastasis 3 years after the operation, with normal follow up sonographic scans and is still under follow up with Government medical college radiotherapy department, Jammu.

\section{DISCUSSION}

In primary SCC of the endometrium, exclusion of cervical SCC extension and squamous differentiation of endometrioid carcinoma is necessary. ${ }^{1}$ The present case was pure SCC of the endometrium. The uterine cervix was free of tumor. There was no endometrioid adenocarcinoma element in the present tumor. Thus, the present case fulfills the criteria of primary SCC of the endometrium. ${ }^{1}$ The frequency of primary SCC of the endometrium is unknown. Primary SCC of the endometrium has been reported to show poorer prognosis than endometrioid carcinoma. ${ }^{1-3}$ The prognosis depends mainly on tumor stage. The present case was FIGO stage IB, was treated with postoperative radiation and adjuvant chemotherapy, and now alive without recurrence or metastasis 15 months after the operation. P53 protein expression is reported to be present in primary SCC of the endometrium. ${ }^{4}$ However, there is a report that p53 mutation is absent in primary SCC of the endometrium. ${ }^{5}$ In the present study, p53 expression was present in $30 \%$ of carcinoma cells, suggesting that p53 gene mutation is present in primary SCC of the endometrium. In the present case, the Ki-67 labeling was very high (70\%). These observations demonstrate the malignant nature of the present case. The pathogenesis of primary SCC of the endometrium is unknown. Several possibilities exist. First, the SCC is a complete malignant squamous differentiation of endometrioid adenocarcinoma. Second, HPV is involved in the pathogenesis of primary SCC of the endometrium. ${ }^{6,5}$ Thirdly, squamous metaplasiadysplasia-SCC sequence is involved in the pathogenesis of primary SCC of the endometrium. ${ }^{7}$ Finally, primary SCC of the endometrium may develop from ectopic cervical tissue in the endometrium. ${ }^{8}$ In the present study, there was no ectopic cervical tissue, squamous metaplasia, or dysplaia. HPV was not investigated in the present case.
Funding: No funding sources Conflict of interest: None declared Ethical approval: Not required

\section{REFERENCES}

1. Silverberg SG, Kurman RJ, Nogales F, Mutter GL, Kubik-Huch RA, Tavassoli FA. Epitheial tumour and related lesions. In: Tavassoli FA, Devilee P, editors. WHO classification of tumours. Pathology and genetics, Tumours of the breast and female genital organs. Lyon: IARC press; 2003:221-32.

2. Kennedy AS, Demars LR, Flannagan LM, Varia MA. Primary squamous cell carcinoma of the endometrium: a first report of adjuvant chemoradiation. Gynecol Oncol. 1995;59:117-23.

3. Goodman A, Zukerberg LR, Rice LW, Fuller AF, Young RH, Scully RE. Squamous cell carcinoma of the endometrium: A report of eight cases and a review of the literature. Gynecol Oncol. 1996;61:5460.

4. Griordano G, D’Adda T, Merisio C, Gnetti L. Primary squamous cell carcinoma of the endometrium: a case report with immune histochemical and molecular study. Gynecol Oncol. 2005;96:876-9.

5. Kataoka A, Nishida T, Sugiyama T, Hori K, Honda $\mathrm{S}$, Yakashiji M. Squamous cell carcinoma of the endometrium with human papilloma virus 31 and without tumor suppressor gene p53 mutation. Gynecol Oncol. 1997;65:180-4.

6. Im DD, Shah KV, Rosenshein NB. Report of three cases of squamous carcinoma of the endometrium with emphasis in the HPV status. Gynecol Oncol. 1995;56:464-9.

7. Zidi YS, Bouraoui S, Atallah K, Kchir N, Haouets S. Primary in situ squamous cell carcinoma of the endometrium with extensive squamous metaplasia and dysplasia. Gynecol Oncol. 2003;88:444-6.

8. Yamamoto Izumi K, Otsuka H, Kishi Y, Mimura T, Okitsu O. Primary small cell carcinoma of the endometrium: a case report and a suggestion of new histogenesis. Int J Gynecol Pathol. 1995;14:75-80.

Cite this article as: Marhatta N, Raina D. Squamous cell carcinoma endometrium. Int J Reprod Contracept Obstet Gynecol 2017;6:2119-20. 